\title{
Vulkansk aktivitet \\ - sidste halvdel af 2008
}

\section{Af geolog Susanne Plesner, GeologiskNyt}

Endnu et år er nu gået, og det er tid til at lave en lille status over, hvad der er sket på vulkanfronten. Der er selvfølgelig til stadighed aktivitet rundt omkring, og ser man på året som helhed, har alle verdensdele nævnt nedenfor været repræsenteret i “aktivitetskalenderen”.

Selv Danmark fik for nylig at mærke, at vores planet er levende, idet et for danske forhold kraftigt jordskælv ramte os en tidlig morgen.

I denne udgave er der sat fokus på Soufriere Hills, Montserrat, der har haft et større udbrud i juli i år og generelt har været ret aktiv i løbet af efteråret, senest med fornyede eksplosioner, askefald og pyroklastiske strømme i starten af december.

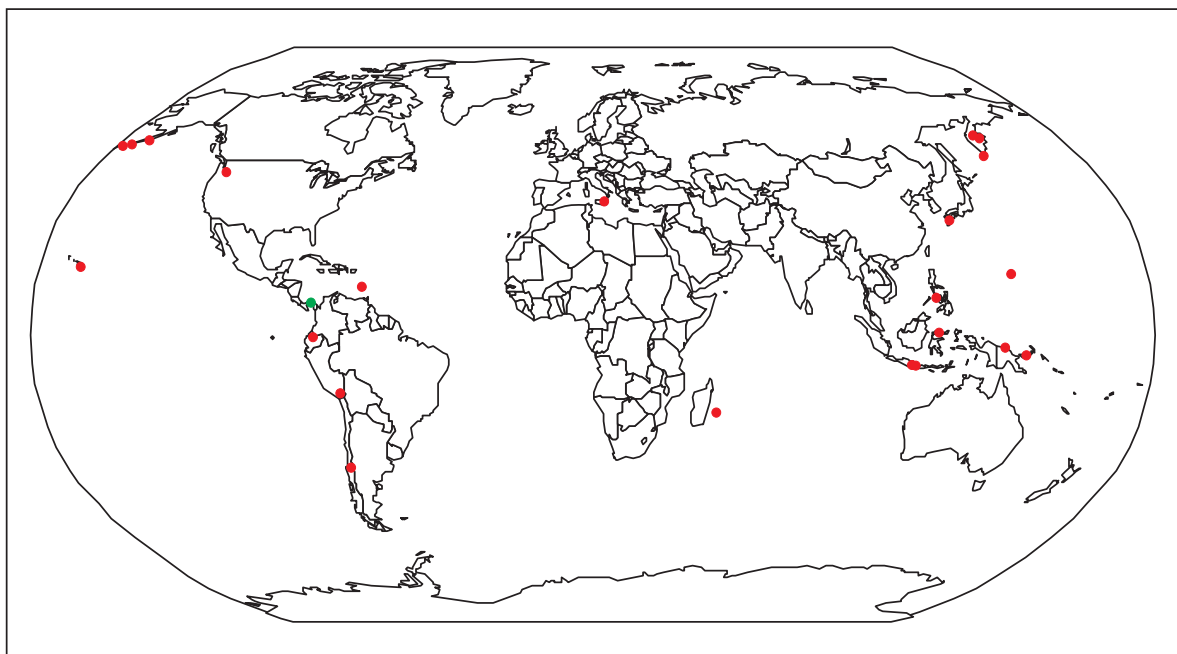

Verdenskort, den med røde fyldte cirkler viser fordelingen af den vulkanske aktivitet de seneste seks måneder. (Grafik: Forfatteren)

\section{Vulkansk aktivitet de sidste 6 måneder}

\section{Nordlige Stillehavsregion}

Kilauea, Hawaii, USA

St. Helens, Washington, USA

Cleveland, Aleuterne, USA

Kasatochi, Aleuterne, USA

Okmok, Aleuterne, USA

Anathan, Marianer Øerne, USA

Suwanose-Jima, Ryukyu Øerne, Japan

Sakura-Jima, Kyushu, Japan

Asama, Japan

Akan, Japan

Mayon, Filippinerne

Taal, Filippinerne

Karangetang, Indonesien

Soputan, Sulawesi, Indonesien

Dukono, Indonesien

\section{Sydlige Stillehavsregion}

Semeru, Java, Indonesien

Galunggung, Java, Indonesien

Batu Tara, Indonesien

Krakatau, Indonesien

Sumbing, Java, Indonesien,

Bagana, Papua Ny Guinea
Rabaul, Papua Ny Guinea

Manam, Papua Ny Guinea

Garbuna Group, New Britain

Ulawun, New Britain

White Island, New Zealand

\section{Indiske ocean}

Piton de la Fournaise, Reunion Island

Barran Island, Andamanerne

Europa

Etna, Italien

Mellemamerika, Mexico og Vestindien

Masaya, Nicaragua

San Cristobal, Nicaragua

Arenal, Costa Rica

Turrialba, Costa Rica

Colima, Mexico

Popocatépetl, Mexico

Fuego, Guatemala

Santa María, Guatemala

Pacaya, Guatamala

Soufriere Hills, Montserrat
Sydamerika

Tungurahau, Ecuador

Reventador, Ecuador

Sangay, Ecuador

Galeras, Colombia

Nevado del Huila, Colombia

Machin, Colombia

Llaima, Chile

Chaiten, Chile,

Villarrica, Chile

Ubinas, Peru

\section{Rusland}

Karymsky, Kamchatka

Shiveluch, Kamchatka

Benzymianny, Kamchatka

Kliuchevskoi, Kamchatka

Chikurachki, Paramushir Islands

\section{Afrika \& Mellemøsten}

Ol Doinyo Lengei, Tanzania

Nyiragongo, Demokratiske Republik Congo

Dalaffilla, Etiopien 
Italienske Etna er stadig aktiv! (Foto: Tom Pfeiffer)

seismiske rystelser med cirka 30 års mellemrum, og så i 1995 begyndte man at se askeudbrud og mindre eksplosioner. Disse mindre hændelser udviklede sig senere samme år til, at en lavadome voksede til en betragtelig størrelse oppe i vulkanen. Herefter kom der et voldsomt udbrud med pyroklastiske strømme, der resulterede i at halvdelen af øen (Montserrat) måtte evakueres, og hovedstaden Plymouth beliggende $5 \mathrm{~km}$ fra vulkanen blev ødelagt hvilket fik store sociale og økonomiske konsekvenser for befolkningen.

Efterfølgende har 1997, 2006 og 2007 været år med ødelæggende udbrud, dødsfald (19 mennesker i 1997) og evakueringer.

I 2008 har vulkanen gjort væsen af sig i februar. Igen i maj måned registrerede man forhøjet seismisk aktivitet fra vulkanen, efterfulgt at askenedfald som i kombination med kraftigt regnvejr skabte en del lahars (vulkanske mudderstrømme). Også en enkelt eksplosion efterfulgt af en pyroklastisk strøm blev registreret. Herefter forholdt vulkanen sig nogenlunde i ro indtil slutningen af juli, hvor seks askeudbrud blev registreret mellem d. 23. og 29. juli. D. 28. var der et eksplosivt udbrud og dele af lavadomen kollapsede, hvilket resulterede i pyroklastiske strømme, der nåede hovedstaden og havet. I de følgende måneder har der været seismisk aktivitet, gentagen rumlen fra vulkanen og lejlighedsvise askeudbrud indtil begyndelsen af december, hvor dele af lavadomen igen kollapsede under en eksplosion. Blokke fra domen trillede ned ad nordvestsiden, og der dannedes igen pyroklastiske strømme, som nåede Plymouth og satte adskillige huse i brand.

I skrivende stund er der fornyede askeudbrud og pyroklastiske strømme fra Soufriere Hills.

\section{Relevante links:}

http://www.volcano.si.edu/reports/usgs/index.cfm?content $=$ archive http://volcano.und.nodak.edu/ http://en.wikipedia.org/wiki/Soufriere_ Hills_volcano 